\title{
EEN EN ANDER OVER DE TOEPASSING VAN ARTIKEL 44 WET OP DE INKOMSTENBELASTING 1964')
}

\author{
door Mr. J. S. Rijkels
}

Met dit artikel wordt beoogd enkele facetten van de praktische toepassing van artikel 44 te belichten, speciaal tegen de achtergrond van de vele fusies welke in deze tijd tot stand komen. Gemakshalve wordt hierna slechts de N.V. genoemd, hoewel mutatis mutandis hetzelfde geldt ten aanzien van andere (binnen- of buitenlandse) vennootschappen met een in aandelen verdeeld kapitaal.

\section{Inleiding}

Voor een juist begrip van artikel 44 lijkt het goed nog even in het kort in te gaan op de belastingheffing van de N.V.-winsten. Deze worden primair getroffen met vennootschapsbelasting, terwijl de uitdelingen, althans in principe, nog eens weer belastbaar zijn bij de aandeelhouders. Van de winst zal doorgaans niet alles terstond worden uitgedeeld. Een stuk wordt gereserveerd. Reservering als zodanig leidt, ondanks de daardoor veelal optredende waardestijging, in principe niet tot belastingheffing bij de aandeelhouders. Maar toch heeft de fiscus latente aanspraken op deze reserves: immers, zodra zij alsnog worden uitgedeeld, komt de fiscus aan bod. Zo bij uitreiking van bonusaandelen, bij inkoop, bij liquidatie. Ondertussen is er een belangrijk verschil in fiscale behandeling al naar de aandelen ten tijde van de uitdeling uit de reserves tot een ondernemingsvermogen behoren, dan wel tot een particulier beleggingsvermogen. Bij de particuliere aandeelhouder is steeds de volle uitkering belast, ook als die uitkering al in de aankoopprijs zou hebben ,gezeten". Bij de aandeelhouder-ondernemer zal de uitkering echter tot het bedrag, dat deze in de aankoopprijs zat, nimmer belast zijn. Indien dus een aandeel op een gegeven ogenblik, naar kan worden verwacht blijvend, van de privé-sfeer in de ondernemingssfeer overgaat zou de fiscus - gegeven het feit, dat de verkoopwinst een onbelaste vermogenswinst is voor de aandeelhouder - zijn latente aanspraken op belastingheffing van de op het tijdstip van overdracht van de aandelen aanwezige reserves verliezen. Tot 1.1.1965 ontbrak behalve voor het geval dat een overdracht plaats had aan de vooravond van de liquidatie van een N.V., in welk geval de particuliere aandeelhouder belasting moest betalen, als was de verkoop een liquidatie - een wettelijke voorziening om een verlies als hier bedoeld tegen te gaan. De gevallen, waarbij het verlies het sterkst naar voren kwam, waren wel de fusies op basis van aandelenruil.

Het gewone type van een aandelenfusie resulteert immers in de overneming van aandelen in de N.V.X van de - hoofdzakelijk - particuliere aandeel-

\footnotetext{
1) De tekst van het artikel luidt: Voorzover de storting op aandelen in een vennootschap bestaat in aandelen in een andere vennootschap wordt, behoudens voor de toepassing van artikel 58 , ten aanzien van alle aandeelhouders slechts als gestort aangemerkt hetgeen op de laatstbedoelde aandelen is gestort.
} 
houders door de N.V.Y tegen uitreiking van aandelen N.V.Y. De N.V.Y neemt de aandelen N.V.X in haar ondernemingsvermogen op voor de waarde ten tijde van de fusie, en zulks bracht tot 1-1-1965 voor de fiscus het verlies mee van zijn latente aanspraken, tot dat tijdstip jegens de particuliere aandeelhouders van de N.V.X opgebouwd met betrekking tot de reserves van deze N.V. Het is voor juist deze gevallen, dat de Wet I.B. sinds 1-1-1965 een bepaling bevat in de vorm van artikel 44 , neerkomend op veiligstelling van de claims door deze als het ware door te schuiven naar de bij de fusie nieuw verkregen aandelen. Zoals hierna nog zal worden uiteengezet, biedt artikel 44 door zijn beperking t.z.v. gevallen, waarin aandelen worden omgewisseld, geen volledige veiligstelling van de fiscale claims. Zo zal bij verkoop tegen contanten de claim wel verloren gaan (behoudens dan bij verkoop in het vooruitzicht van liquidatie). Vgl. onderdeel 3 hierna.

\section{Terminologie}

Artikel 44 maakt het noodzakelijk ten aanzien van het kapitaalbegrip een dubbele terminilogie te hanteren:

één in beginsel ontleend aan het handelsrecht en één speciaal voor de toepassing van de inkomstenbelasting. Het is gebruikelijk voor de laatste voorzover mogelijk de handelsrechtelijke termen te bezigen, voorafgegaan door het woordje fiscaal. (Dus agio $\rightarrow$ fiscaal agio). In feite is de toevoeging ,fiscaal" niet geheel adaequaat, aangezien hetgeen voor de inkomstenbelasting geldt, niet steeds geldt voor andere belastingen (vgl. onderdeel 8 hierna). Het verschil tussen het gestorte kapitaal in handelsrechtelijke zin en dat in fiscale zin (in de hiervoor aangeduide beperkte betekenis) wordt veelal aangeduid als besmet agio, disagio of diskapitaal.

\section{Werking uitsluitend bij inbreng van aandelen tegen uitreiking van aandelen (kortweg: aandelenruil)}

Artikel 44 is alleen van betekenis bij aandelenruil (maar dan ook bij elk type aandelenruil; derhalve ook buiten het geval van fusie). Worden aandelen in een N.V. aan een andere N.V. overgedragen tegen contanten, tegen al of niet converteerbare obligaties etc., dan is het artikel niet van toepassing. Het artikel vindt evenmin toepassing wanneer obligaties enz. worden ingebracht tegen uitreiking van aandelen. In de praktijk komen ondertussen dikwijls mengvormen voor. Het begin van artikel 44 („Voorzover”) laat geen ruimte voor de gedachte, dat het artikel dan niet voor een gedeelte van toepassing zou kunnen zijn. Zie voor de bij dergelijke mengvormen optredende toerekeningsproblemen onderdeel 7 hierna.

Het gaat het bestek van dit artikel te buiten om in te gaan op de ongelijkheid die in feite optreedt door de beperking van artikel 44 tot gevallen van aandelenruil. In onderdeel 5 worden over dit onderwerp nog enkele zijdelingse opmerkingen gemaakt. 


\section{Het praktische belang van artikel 44}

Artikel 44 bewerkstelligt doorschuiving van fiscale claims. De belangrijkste situaties op wat langere termijn waarbij het artikel een rol speelt zijn: (Zie ook de inleiding hiervoor)

- uitreiking van bonusaandelen. Alleen bonusaandelen ten laste van onbesmet agio zijn onbelast, de overige zijn belast. Zie ook onderdeel $7 \mathrm{~b}$;

- inkoop van aandelen. Hetgeen boven het ficaal gestorte bedrag wordt betaald levert belastbaar inkomen op, behoudens in bepaalde gevallen (vgl. BNB 1957/20);

- liquidatie. De liquidatie-uitkeringen zijn belastbaar voorzover zij het fiscaal gestorte kapitaal overtreffen. Met liquidatie wordt op een lijn gesteld verkoop in het vooruitzicht van liquidatie (art. 31, lid 3 Wet I.B.);

- vervreemding van tot een aanmerkelijk belang behorende aandelen. De minimum-verkrijgings-(c.q. overdrachts)prijs wordt tenminste gesteld op het gemiddeld op de desbetreffende aandelen gestorte kapitaal. Dit gestorte kapitaal kan, althans naar veler mening, mede de invloed van artikel 44 ondergaan. Zie verder onderdeel 12a;

- het „,schoonmaken" van de balans. Niet zelden is het fiscaal gestorte bedrag lager - soms aanmerkelijk lager - dan het op de commerciële balans opgenomen gestorte kapitaal. Wie deze discrepantie wil opheffen, anders dan door bonusaandelen uit te reiken, zal de fiscale gevolgen moeten overwegen. Verwezen zij naar onderdeel $12 \mathrm{~b}$.

\section{De reikwijdte}

a. Algemeen

Reeds in de inleiding is naar voren gekomen, dat de fiscus vooral heeft gedacht aan het verlies van aanspraken, die hij jegens particuliere aandeelhouders heeft opgebouwd. Nu zal een aandeel, zeker van de gemiddelde beurs-N.V., vaak in de loop van de tijd diverse eigenaren hebben gehad, en niet allen zullen particuliere beleggers geweest zijn. Doordat de wetgever de materie vanuit een beperkte gezich tshoek heeft benaderd, kunnen gemakkelijk anomalieën optreden. Met name leidt artikel 44 bij letterlijke toepassing in een aantal gevallen tot dubbele heffing, c.q. tot heffing waar dat niet logisch lijkt. Hierna zijn enkele van die gevallen vermeld.

Prof. Smeets geeft in De Naamloze Vennootschap van december 1965 het voorbeeld van een middenstander, die zijn bedrijf - tot welks vermogen aandelen in de (N.V. Nederlandsche) Middenstandsbank behoren - inbrengt in een door hem opgerichte N.V. De middenstander moet in principe afrekenen, ook over de koerswinst op de aandelen Middenstandsbank, welke winst immers deel uitmaakt van de overdrachtswinst. Voor de toepassing van artikel 44 wordt echter niet de werkelijke waarde van de aandelen Middenstandsbank als gestort aangemerkt maar slech ts het op die aandelen gestorte bedrag. Dubbele belastingheffing treedt nu op voor het kleinste van de twee volgende bedragen:

- het verschil tussen werkelijke waarde en gestort kapitaal;

- het verschil tussen werkelijke waarde en boekwaarde. 
Het is de vraag of men kan zeggen, dat voor deze situaties artikel 44 verder gaat dan billijk genoemd mag worden. De Staatssecretaris van Financiën heeft tijdens de parlementaire behandeling van de Wet I.B. toegezegd onbillijkheden van overwegende aard soepel te zullen behandelen.

Mijns inziens doet zich in het voorbeeld van Prof. Smeets zo'n onbillijkheid voor.

Een verwant geval doet zich voor bij de zgn. geruisloze omzetting van een eenmanszaak in een N.V. Indien tot het ondernemingsvermogen van de eenmanszaak aandelen in een N.V. behoren, welke bij de nieuwe N.V. een deelneming gaan vormen, zal in zoverre geen claim vennootschapsbelasting ontstaan. De tekst van de standaardvoorwaarden laat mijns inziens de interpretatie toe, dat dan het verschil tussen reële waarde en boekwaarde van de in te brengen aandelen ten volle in aandelenkapitaal kan worden omgezet. Tevens echter werkt artikel 44. Het Ministerie van Financiën blijkt echter de voorwaarde te stellen dat het tegenover de ingebrachte aandelen uit te geven aandelenkapitaal niet hoger mag zijn dan het op de ingebrachte aandelen gestorte kapitaal.

$\mathrm{Bij}$ de hiervoor bedoelde gevallen sluit aan het geval dat de N.V. A de aandelen van de N.V. B, dochter van de N.V. C, middels aandelenruil verwerft. Toepassing van artikel 44 schiet hier mijns inziens over haar doel heen, aangezien nu in principe twee claims krachtens dit artikel ontstaan:

één via de aandelen N.V. C en één via de aandelen N.V. A. Slechts op de eerste behoort mijns inziens de claim te rusten.

Aan de dubbele claim kan in principe worden ontkomen indien de N.V. B haar aandelenkapitaal vóór de ruil verhoogt via omzetting van reserves in kapitaal. Dit vergt echter wel $2 \frac{1}{2} \%$ registratierecht. Toepassing van de hardheidsclausule lijkt mij een reëlere oplossing.

Ook als aandelen aanvankelijk tot een deelneming hebben behoord en vervolgens in privé handen zijn gekomen, zal via de toepassing van artikel 44 een claim ontstaan over een bedrag, dat via de deelnemingsvrijstelling al was vrijgesteld.

Op een zeer bijzonder geval - wederkerig aandeelhouderschap, gecreëerd via aandelenruil - wees nog Stil in losbladig Fiscaal Weekblad FED, I.B. art. 7 (i) $1950,307$. Ik memoreer dit hier slech ts volledigheidshalve.

\section{b. Dividendbelasting}

In de Wet op de Dividendbelasting 1965 ontbreekt een overeenkomstige bepaling als art. 44. Geldt artikel 44 wellicht rechtstreeks voor de dividendbelasting? Ik meen, dat gelet op het uitzonderingskarakter van het artikel, het antwoord ontkennend moet luiden.

\section{c. Buitenlandse N.V.'s}

Artikel 44 geld t naar letter en geest niet slechts voor aandelen in Nederlandse N.V.'s maar ook voor aandelen in buitenlandse N.V.'s. Aankoop van buitenlandse aandelen vrijwaart een Nederlandse aandeelhouder niet voor de werking van het artikel. 


\section{d. Niet ingezetenen}

Niet-ingezetenen kunnen de werking van het artikel ondervinden indien zij voor de opbrengst van de betreffende aandelen onder de Nederlandse inkomstenbelasting vallen. Dit zijn dus met name niet-ingezetenen met een aanmerkelijk belang in een Nederlandse N.V. voor wie de belastingplicht niet krach tens een verdrag ter voorkoming van dubbele belasting is vervallen.

\section{e. Mogelijkheid tot ontgaan?}

Van Soest-Van Soest, Belastingen, 11 e druk (1970), blz. 118, handhaven hun reeds in de $10 \mathrm{e}$ druk neergelegde stelling dat de werking van artikel 44 gemakkelijk kan worden on tgaan, door eerst aandelen te plaatsen met agio tegen contanten en daarna de aandelen die men anders zou laten inbrengen, te kopen. Ongetwijfeld is een N.V. vrij eerst aandelen te plaatsen tegen storting in contanten en daarna met de opbrengst de door haar begeerde aandelen in een andere N.V. te kopen, maar als e.e.a. zich afspeelt tussen dezelfde personen volgens een vooraf vastgesteld plan, is voorzichtigheid op zijn plaats.

\section{De maximumregel: een kwestie van redelijkheid}

Prof. Dr. D. Brüll heeft in De Naamloze Vennootschap van januari 1968 een interessante beschouwing gewijd aan de in artikel 44 neergelegde regel storting = storting. $\mathrm{Zijn}$ conclusie is, dat artikel 44 de hantering van deze regel in principe zonder beperking toestaat. Dit standpunt leidt er o.a. toe, dat indien de N.V. A de aandelen van de praktische lege N.V. B verwerft (gestort kapitaal stel $f 1.000 .000,-$, werkelijke waarde van alle aandelen stel $f 2.000,-$ ) tegen uitreiking van een eigen aandeel van $f 1.000$,- (uitgiftekoers $200 \%$ ), het fiscaal gestorte kapitaal van de N.V. A word t verhoogd met $f 1.000 .000,-$ in plaats van met $f 2.000,-$, zoals het geval zou zijn zonder toepassing van artikel 44 . Deze gevolgtrekking zou duidelijk ten voordele strekken van de oude aandeelhouders van de N.V. A. Op deze zienswijze is o.a. kritiek geleverd door Drs. K. van der Heeden in Maandblad Belastingbeschouwingen van juni 1968 (noot 2). Zijns inziens duidt het woordje ,slechts" in artikel 44 aan, dat artikel 44 niet bewerkt dat het commerciëel gestorte kapitaal wordt verhoogd. In principe $\mathrm{kan} i \mathrm{k}$ mij verenigen met deze kritiek op Brüll's opvatting. Ik zou echter een uitzondering - eventueel via toepassing van de hardheidsclausule - willen bepleiten voor het geval dat duidelijk is, dat de regel storting = storting in belangrijke mate ten gunste van de voormalige aandeelhouders van de overgenomen N.V. zou werken. Indien b.v. de aandelen N.V.X een waarde hebben van $100 \%$ (fiscaal gestort $200 \%$ ), terwijl de aandelen N.V.Y ook $100 \%$ waard zijn (gestort eveneens 200\%) zie ik niet in waarom bij. overneming van. $X$ door $Y$ niet $200 \%$ als fiscaal gestort kapitaal kan blijven aangemerkt. Dit positieve aspect van artikel 44 sluit zeer goed aan bij de doorschuivingsgedachte. 


\section{Toerekeningsproblemen}

a. Toerekening indien geen sprake is van zuivere aandelenruil Artikel 44 werkt zoals reeds opgemerkt (onderdecl 3) ook indien behalve aandelen andere vormen van tegenprestatie in het geding zijn. Zo is het mogelijk, dat de overnemende N.V. behalve aandelen ook contanten o.i.d. betaalt. Omgekeerd is het mogelijk dat behalve aandelen ook andere zaken worden ingcbracht (overigens komt deze laatste situatie weinig frequent voor). Beide gevallen worden hierna toegelicht.

Stel de N.V. B neemt de aandelen (nominale waarde $f(1.000,-)$ ) van de N.V. A over. De omruilwaarde van deze laatste bedraagt $f 3.000,-$, het (fiscaal!) daarop gestorte bedrag $f 1.200,-$. De tegenprestatic bestaat uit f $1.000,-$ nominaal aandelen $B$, koers $150 \%$, en $f 1.500$, - obligaties. Men zou nu voor de toepassing van artikel 44 drie wegen kunnen bewandelen.

Allereerst zou men kunnen uitgaan van de regel:

Zo veel mogelijk (fiscaal) gestort kapitaal tegenover (fiscaal) gestort kapitaal stellen. Dan zou het resultaat zijn, dat per uitgegeven aandeel B cx artikel 44 $f 1.200,-$ is gestort, zodat er t.o.v. de handelsrechtelijke storting ad $f 1.500,-$ een disagio van $f 300,-$ ontstaat. Men zou deze methode de methode ,aan de voet" kunnen nocmen.

De tweede methode is juist omgekeerd aan de eerste: hierbij worden zoveel mogelijk obligaties N.V. B gesteld tegenover het gestorte kapitaal N.V. A. Aangezien er $f 1.500,-$ obligaties worden uitgegeven terwijl het gestorte kapitaal $f 1.200,-$ is, zou een en ander betekenen, dat het gestorte kapitaal (in de zin van art. 44) van de N.V. B met nihil wordt verhoogd.

De derde methode is de evenredigheidsmethode. Bij deze methode wordt het op de aandelen N.V. A (fiscaal) gestorte kapitaal ad f 1.200,- omgeslagen over de beide componenten van de tegenprestatic en wel naar rato van de reële waarde daarvan. Nu de tegenprestatic bestaat uit aandelen ter waarde van $f 1.500,-c n$ obligaties ter waarde van $f 1.500,-z a l$ tegenover de uitgegeven aandelen B sleclits $f 600,-$ fiscaal gestort kapitaal staan.

Juridisch staat de evenredigheidsmethode - die in casu nadelig voor de aandeelhouders is - m.i. het sterkst, aangezien sprake is van een gemengde tegenprestatie die berust op één enkele overeenkomst. Niettemin zou ik de eerst bedoelde methode in bepaalde gevallen mede op praktische gronden verdedigbaar achten, b.v. indien slechts sprake is van uitkeringen ter afronding.

Bij de omgekeerde situatic - behalve aandelen worden ook andere zaken ingebracht - zic ik geen bijzondere problemen. De andere zaken zullen voor hun werkelijke waarde als storting moeten worden aangemerkt; m.b.t. de ingebrachte aandelen geldt slechts het daarop (fiscaal) gestorte bedrag als storting in de zin van artikel 44.

Zijn aan beide zijden diverse soorten aandelen in het geding dan moet m.i. per categoric nieuw uitgegeven aandelen worden nagegaan welke aandelen daarop gestort worden. Worden b.v. preferente aandelen omgewisseld tegen preferente aandelen dan bedraagt de storting op laatst bedoelde aandelen het op de ingeleverde preferente aandelen gestorte bedrag. Deze splitsing vloeit

$m a b \quad b l z .284$ 
voort uit de woorden .,op de desbetreffende aandelen”, waaronder aandelen van eenzelfde soort dienen te worden verstaan. (vgl. M.v.A. Tweede Kamer Wet I.B. 1964, blz. 42).

\section{b. (Agio)bonussen}

Heeft een N.V. een handelsrechtelijk agio, dat echter fiscaal slechts tendele als gestort kapitaal wordt aangemerkt, en zou zij bonusaandelen willen toekennen, dan rijst de vraag, hoe deze bonussen moeten worden toegerekend aan de diverse reserves (zie over het boekingsprobleem onderdeel 8). De vraag is natuurlijk alleen van belang indien niet het gehele (handelsrechtelijke) agio wordt uitgckeerd. Tijdens de parlementaire behandeling heeft de tocnmalige Staatssecretaris bevestigd, dat de N.V. hier een volledig keuzerecht heeft, zoals zij dat ook heeft t.a.v. de vraag: agiobonus of winstbonus. Fiscaal is het ,besmette" agio gelijk een winstreserve. Wel zal in het besluit tot uitreiking m.i. de keuze duidelijk moeten worden aangegeven.

Bij agiobonussen doet zich nog een ander probleem voor, nl. of een fiscale agioreserve in het kader van een aandelenruil via de werking van art. $44 \mathrm{kan}$ worden aangetast. Deze vraag is in het bijzonder van belang

- indien de nominale waarde van de bij de aandelenruil uitgegeven aandelen het op de ingebrachte aandelen gestorte bedrag overtreft - er ontstaat dan een disagio of juister nog een diskapitaal -;

- indien een nieuwe emissie met agio word t overwøgen, terwijl vóór de emissic het fiscaal gestorte kapitaal lager is dan de nominale waarde van de uitstaande aandelen.

Bij samenvoeging van het gestorte kapitaal tot één bedrag en omslag van dit totaal over alle aandelen zou kunnen blijken, dat de oude agioreserve c.q. het nieuw te verwerven agio in een stuk ,nominale" waarde (in handelsrechtelijke zin) verdwijnt, zodat in zoverre géén voor uitreiking van belastingvrije (agio)bonussen aanwezige agioreserve meer aanwezig is, c.q. ontstaat. Zou men dc oude c.q. nieuw agioreserve in deze gevallen apart mogen administreren, dan zou de mogelijkheid tot uitkering van belastingvrije agiobonussen blijven bestaan.

Op dit punt hecrst geen communis opinio. De indruk bestaat dat de fiscus slechits één gestort kapitaal, opgevat als saldo, aanvaardt. De fiscale medewerkcr van Het Financiële Dagblad heeft in een tweetal artikelen in dat blad van 29 en 30 augustus 1968 scherp stelling genomen tegen het fiscale standpunt. Maar de Staatssecretaris heeft zich tijdens de behandeling van hoofdstuk IX $\mathrm{B}$ (Financiën) van de rijksbegroting voor het dienstjaar 1969 (Handelingen Twecde Kamer, zitting 1968-1969, blz. 2276) t.a.v. deze interpretatie zeer voorzichtig opgesteld. Het laatste woord is dus aan de rechter. Mijns inziens sluit de gedaclite van het afzonderlijk boeken beter aan bij de jurisprudentie, waarin immers aan boekingen overwegende betekenis wordt toegekend. Zie ook het volgende onderdeel.

\section{c. Inkoop; terugbetaling}

Stel de N.V. A met destijds een nominaal, tevens gestort, kapitaal van $f 100.000,-$ hecft een aantal jaren geleden de aandelen N.V. B, gestort kapi- 
taal $f 20.000,-$, overgenomen tegen uitgifte van $f 100.000$,- eigen aandelen.

Het nominale aandelenkapitaal bedraagt thans dus $f 200.000$,-, waarop fiscaal gestort $f 120.000,-$. Als vervolgens nom. $f 50.000,-$ aandelen zou worden ingekocht - stel tegen $300 \%$ dus tegen $f 150.000,-$ - dan rijst de vraag: Wat is belastbaar voor de inkomstenbelasting?

Ook hier zijn weer dezelfde methoden denkbaar als onder a. hiervoor vermeld. De evenredigheidsmethode lijkt mij het meest voor de hand te liggen. Dit leidt tot het volgende. Ingekocht wordt $f 50.000,-$ nominaal, dit is $25 \%$ van het uitstaande aandelenkapitaal. Hierop is fiscaal gestort $25 \%$ van $f 120.000,-=f 30.000,-$. Belastbaar is dan $f 150.000,--f 30.000,--=$ $f 120.000,-$. Mijns inziens is in de daarvoor in aanmerking komende gevallen het proportionele tarief $(20 \%-40 \%)$ van toepassing.

$\mathrm{Bij}$ terugbetaling van kapitaal zal m.i. eenzelfde oplossing gevolgd moeten worden. Het enkele feit, dat de handelsrechtelijk voorgeschreven procedure voor statutenwijziging is gevolgd, kan er m.i. niet toe leiden dat wat handelsrechtelijk als terugbetaling van kapitaal geldt, niet deels als belastbaar inkomen wordt aangemerkt. In deze zienswijze zal dit inkomen zelfs progressief moeten worden belast, al lijkt dit niet steeds redelijk.

\section{Boekingen}

Wat de boekingen van het gestorte kapitaal betreft is er langzamerhand in Nederland een vrij chaotische toestand ontstaan. Er blijken namelijk vele soorten gestort kapitaal te kunnen worden onderkend, zoals:

(i) Het gestorte kapitaal in handelsrechtelijke zin;

(ii) Het gestorte kapitaal volgens de commerciële balans;

(iii) Het gestorte kapitaal volgens de fiscale balans;

(iv) Het gestorte kapitaal volgens artikel 44 Wet I.B.;

(v) Het gestorte kapitaal voor het registratierecht.

\section{Ad (i)}

Hieronder zal men dienen te verstaan het bedrag, dat in werkelijkheid is gestort (vóór aftrek van kosten en dergelijke) verminderd met officiële kapitaalverminderingen (kapitaalterugbetalingen; afstempelingen enz.)

Ad (ii)

De commerciële balans wijst dikwijls een gestort kapitaal aan, dat afwijkt van het sub (i) bedoelde kapitaal. De oorzaken kunnen zeer verschillend zijn, zoals:

- in de commerciële balans is de agioreserve opgevoerd aan de hand van een forfaitaire maatstaf, onafhankelijk van de werkelijke waarde van de inbreng. (b.v. wanneer bij storting d.m.v. aandelen in een andere N.V. van een vaste koers wordt uitgegaan, of wanneer aandelen van een overgenomen vennootschap worden gewaardeerd op nominaal kapitaal plus zichtbare reserves, enz.)

- de emissiekosten zijn afgeboekt

- in de loop der tijd zijn bepaalde andere kosten en voorzieningen of verliezen afgeboekt. 
Ad (iii)

Niet zelden wijkt de "fiscale balans" van een N.V. af van de commerciële, ook op het gebied van het gestorte kapitaal. De oorzaak van het verschil ligt soms bij de verwerking van de emissiekosten. In de commerciële stukken zijn deze kosten rechtstreeks ten laste van de V-en W-rekening gebracht, in de fiscale balans zijn zij afgeboekt op het agio, veelal op grond van een onjuiste interpretatie van artikel 13 Besluit op de vennootschapsbelasting 1942 (vgl. BNB 1961/218). Een andere keer blijkt het verschil toe te schrijven aan de verwerking van een inkoop van eigen aandelen, welke fiscaal als onttrekking is aangemerkt.

Ad (iv)

Deze vorm van gestort kapitaal behoeft hier geen verdere toelichting.

$\operatorname{Ad}(v)$

Zoals bekend, kan bij aandelenruil in het kader van een fusie op bepaalde voorwaarden een vermindering van registratierecht worden verkregen (Resolutie van 28 september 1962, BNB 1963/41).

De vermindering komt neer op verlaging van het normale registratierecht ad $2 \frac{1}{2} \%$ over de verkoopwaarde van de inbreng (art. 46 io. 49 Registratiewet 1917) tot op $\frac{3}{4} \%$ over de nominale waarde van de uitgegeven aandelen. Voorwaarde voor vermindering is, dat het verschil tussen de werkelijke waarde van de storting en de nominale waarde van de uitgegeven aandelen niet als gestort kapitaal in de zin van artikel 48 van de Registratiewet 1917 wordt aangemerkt, zodat ten laste van dit verschil geen aandelen kunnen worden uitgegeven zonder betaling van registratierecht. Aldus wordt voor de toepassing van de Registratiewet in feite eveneens een eigen kapitaalbegrip geïntroduceerd.

De Wet op de jaarrekening van ondernemingen - inwerkingtredingsdatum 1 mei '71 - verplicht de ondernemingen hun geplaatste en gestorte kapitaal, gesplitst naar soorten aandelen, alsmede hun reserves inclusief agioreserve in de balans op te nemen (art. 20). In de Memorie van Toelichting heet het, dat de vermelding van de agioreserve van belang is, o.a. met het oog op de fiscale gevolgen. Hoewel wel duidelijk is wat hiermede word t bedoeld, is de toepassing van het voorschrift blijkens het zojuist betoogde niet zo eenvoudig.

Een andere complicatie wordt gevormd door het feit, dat de Hoge Raad meermalen heeft beslist, dat fiscaal van agio slechts sprake kan zijn als deze boekhoudkundig nog aanwezig is (zie vooral B 8268), zij het dat een ,,geheim agio" onder omstandigheden alsnog kan worden geboekt (Zie B 7608; dit speelt vooral bij de sub (ii) hiervoor bedoelde forfaitaire boekingen een rol).

Naar mijn mening is onverkorte toepassing van vorenbedoelde arresten gaandeweg erg bezwaarlijk geworden. Mijns inziens kan het bedrag, dat in fiscale zin als gestort kapitaal geldt, slechts extra-comptabel worden vastgesteld. Afzonderlijke vaststellingen zijn daarbij nodig voor de inkomstenbelasting en het registratierecht. Basis zouden de oorspronkelijke stortingen in handelsrechtelijke zin kunnen vormen. Voor de I.B. volgen de daarop toe te 
passen correcties uit o.a. de toepassing van artikel 44 , de inkooparresten etc. Voor het registratierecht vloeien de correcties in het bijzonder voort uit de aanvaarding van de voorwaarden die gesteld worden bij een vermindering van registratierecht in het kader van een fusie of interne reorganisatie. In de commerciële balans kan dan een eigen systeem gevolgd worden zonder vrees voor fiscale repercussies.

In een noot bij deze balans zou het bedrag van het gestorte kapitaal voor de inkomstenbelasting moeten worden opgegeven. Ik realizeer mij, dat invoering van het hier omschreven systeem ook impliceert dat o.a. vroegere afschrijvingen van kosten, verliezen etc. weer als fiscaal gestort kapitaal herleven. Een bezwaar acht ik dit niet. Er is alles voor te zeggen om een ,,inhaal” van vroegere verliezen in de sfeer van de beide hiervoor bedoelde belastingen toe te staan. De claim van de fiscus op de reserves is immers ook niet aan een bepaalde periode gebonden, zodat budgettaire e.d. overwegingen - die b.v. wel gelden voor de beperkte verliescompensatie - hier mijns inziens buiten beschouwing kunnen blijven.

Anders dan Prof. Dr. J. H. Christiaanse in zijn opstel in de Smeets-bundel en wellicht ook anders dan Mr. E. J. Korthals Altes in zijn bespreking van deze bundel in MBB van oktober 1968 - zie ik eigenlijk alle aanleiding voor de erkenning van een eigen fiscaal kapitaalbegrip. ${ }^{2}$ ) Dienovereenkomstig zie ik voor een eliminatie van informele kapitaal-stortingen (vgl. W. E. Kremer in dit tijdschrift, maart 1964) ook geen reden, temeer omdat de Hoge Raad in zijn arrest van 3 april 1957 (BNB 1957/165) zeer nadrukkelijk heeft gesteld ,dat er gevallen kunnen zijn waarin voor de toepassing van het belastingrecht moet worden aangenomen, dat inbreng van kapitaal in een naamloze vennootschap heeft plaats gevonden, niettegenstaande van een storting op de aandelen geen sprake was" (het onderhavige arrest betrof in principe alleen de vennootschapsbelasting).

\section{Invloed op de waardering}

Het komt regelmatig voor, dat bij een aandelenruil aandelen zijn betrokken, die zwaar ,beclaimd" zijn. De andere aandeelhouders nemen dan een deel van de ingebrachte claim over. Het lijkt juist bij de waardering van de ingebrachte aandelen daarmee rekening te houden. Hoe hoog moet de claim worden gewaardeerd?

De belangrijkste gelegenheden waarbij belastingheffing kan optreden zijn vermeld in onderdeel 3 . In het algemeen blijkt de kans op honorering van de claim door de fiscus op korte termijn vrij klein. Veelal zal de ,discount" dan ook op niet meer dan enkele procenten van het verschil tussen reële waarde en fiscaal gestort kapitaal kunnen worden vastgesteld. Zie ook Prof. J. E. A. M. van Dijck in „Weekblad voor fiscaal Recht”, no. 4676 van november 1963.

\footnotetext{
2) Bezinning daarop zou ook kunnen leiden tot afschaffing van de m.i. weinig aanvaardbare heffing op bonusaandelen.
}

$m a b$ blz. 288 


\section{Vaststelling gestort kapitaal}

Voor de N.V. is het van groot belang - zowel uit beleidsoogpunt als in verband met de Wet op de jaarrekening van ondernemingen - te weten hoe hoog haar fiscaal gestorte kapitaal is. Nergens is echter een vaststellingsprocedure voorgeschreven. Zolang zal de praktijk zich moeten behelpen met een eigen berekening, al of niet gefiatteerd door de inspecteur. Juister lijkt mij de mogelijkheid te openen een beschikking te vragen.

\section{Het element terugwerkende kracht}

$\mathrm{Bij}$ de discussies rondom de invoering van artikel 44 heeft de zgn. terugwerkende kracht van het artikel een grote rol gespeeld. De tekst van het artikel is n.l. zo ruim, dat deze ook ziet op inbreng van aandelen, die vóór de inwerkingtreding van de Wet I.B. (1 januari '65) plaats heeft gehad, zij het met een beperking van de terugwerkende kracht tot 1 januari 1946. Dit terwijl volgens de in die vroegere periode geldende wetgeving een zodanige aandelenruil tot verlies van de claim van de fiscus leidde. Wel had de Staatssecretaris van Financiën in een resolutie (BNB 1961/155) aan zijn ambtenaren opgedragen het standpunt in te nemen dat bij aandelenruil in het kader van een concentratie van vennootschappen - dus niet in andere gevallen van inbreng van aandelen - het zgn. fusie-agio niet als fiscaal gestort kapitaal dient te worden erkend, maar deze resolutie had geen kracht van wet.

Het lijkt mij ondanks alles moeilijk te ontkennen dat de Wet alsnog een claim heeft gelegd op bedragen die volgens de voordien bestaande wettelijke regering moesten worden aangemerkt als belastingvrije vermogenswinsten. Bij een herziening van het artikel zou men er dan ook goed aan doen de terugwerkende kracht te laten vervallen, mede omdat het budgettaire verlies voor de fiscus m.i. de facto gering zal zijn. Het gevolg van een dergelijke wijziging zou zijn, dat voor 1 januari 1965 liggende stortingen middels aandelen in een andere N.V. steeds voor de werkelijke waarde van de inbreng in aanmerking moeten worden genomen.

\section{Enkele bijzondere gevallen}

\section{a. Aanmerkelijk Belang}

Het verband tussen het aanmerkelijk belang en het gestorte kapitaal manifesteert zich met name via de minimum verkrijgings- (c.q. overdrachts)prijs. Artikel 39, 5e lid Wet I.B. bepaalt immers dat deze tenminste gesteld word op het ,gemiddeld op de desbetreffende aandelen gestorte kapitaal".

C. J. Sleddering heeft in WFR 4954 van 17 juli '69 gepleit voor een zelfstandige betekenis van dit laatste begrip in artikel 39 , los van artikel 44 . Het gaat mij echter vooralsnog te ver om een uitdrukking, die mede door de rechtspraak een vast omlijnde betekenis heeft gekregen, en zeker niet toevallig ook in artikel 39 is gebezigd, afwijkend te interpreteren. Tot aan een eventuele wetswijziging zal de minimum-verkrijgingsprijs mijns inziens dan ook moeten worden bepaald mede met inschakeling van artikel 44. Hierop 
wijst m.i. ook de plaats van het artikel in Hoofdstuk Il, afdeling 5 (Bijzondere bepalingen) van de Wet.

Nog in ander opzicht bestaat er verband tussen aanmerkelijk belang en artikel 44. Indien n.l. ter gelegenheid van de inbreng van tot een aanmerkelijk belang behorende aandelen wel $20 \%$ inkomstenbelasting verschuldigd is (tijdens de parlementaire behandeling is gewezen op de inbreng in een holding; men kan daaraan toevoegen het geval, waarin de tegenprestatie niet uitsluitend in aandelen bestaat), staat deze heffing aan de toepassing van artikel 44 niet in de weg, hoewel hier materiëel een dubbele claim wordt gelegd op de winstreserves van de N.V. Mede gelet op de toezeggingen van diverse Staatssecretarissen mag men mijns inziens rekenen op een soepele hantering van de hardheidsclausule.

\section{b. Herkapitalisatie}

Artikel 44 bepaalt, dat voor de toepasing van artikel 58 Wet I.B. (herkapitalisatie) niet wordt teruggegrepen naar het fiscaal gestorte kapitaal.

Anders gezegd:

Voor de vraag of sprake is van de vereiste minimumkapitaalverhoging moet worden gelet op het handelsrechtelijke (!) nominaal gestorte kapitaal. Dit zal dikwijls hoger liggen dan het fiscaal gestorte kapitaal.

Een tweede vraag rond de herkapitalisatie betreft de kwestie:

kan een besmet agio via een herkapitalisatic omgezet worden in aandelenkapitaal?

Mijns inziens wel. Vgl. D. Scheer, TVVS van juli/augustus 1966.

Voor het ,aangetaste" deel van het nominale kapitaal is herkapitalisatie niet mogelijk.

Het Ministerie van Financiën blijkt in de praktijk enkele keren afkoop van het disagio te hebben toegestaan ook zonder officiële herkapitalisatie, maar blijkbaar wel op basis van het herkapitalisatietarief. Gelet op de contante waarde waarop de fiscale claim doorgaans kan worden gewaardeerd - enkele procenten - is dit tarief aan de hoge kant. Belanghebbenden doen er goed aan zich dit te realiseren.

\section{c. Ingekochte eigen aundelen}

Soms blijken bij een fusie tot het vermogen van de N.V., waarvan de aandelen worden ingebracht, ingekochte eigen aandelen te behoren. In zeer vele gevallen zullen die aandelen fiscaal als ingetrokken moeten worden beschouwd. Welke invloed oefenen deze aandelen uit op de toepassing van artikel 44? Naar mijn mening zal het gestorte kapitaal van de N.V. (fiscaal) moeten worden bepaald door de oorspronkelijke nominale waarde en het oorspronkelijk agio naar evenredigheid van de ingekochte aandelen te verminderen.

\section{d. Valutaproblemen}

Een apart probleem vormen aandelen in buitenlandse N.V.'s. Hoe het gestorte kapitaal van deze N.V.'s naar Nederlandse maatstaven te bepalen? Dat is, zoals Van Soes en van Soest, Belastingen 11e druk, blz. 187 terecht 
opmerken een moeilijke zaak. Overigens niet alleen voor aandelen van grote N.V.'s als General Motors. Als een analyse niet mogelijk is, zal zoveel mogelijk aansluiting bij de kapitaalrekening gezocht moeten worden. Mijns inziens zal de inspecteur in voorkomende gevallen moeten aantonen dat het bedrag daarvan niet als fiscaal gestort kapitaal kan worden aangemerkt. Wat de omrekening betreft lijkt mij de waardeverhouding ten tijde van de oorspronkelijke storting beslissend, en niet die tentijde van de latere aandelenruil.

Alleen op deze manier bereikt men gelijkheid tussen Nederlandse en buitenlandse aandelen (hetzelfde probleem doet zich voor bij liquidatie van een buitenlandse N.V.). Men vergelijke BNB 1960/128.

\footnotetext{
Dit artikel werd geschreven voor het rapport inzake „De heffing van Inkomstenbelasting van bonusaandelen en stockdividenden" van de Commissie Hofstra verscheen.
} 